Domingo Melfi.

\title{
PANORAMA UNIVERSAL
}

\section{EL DRAMA PERUANO}

OS viajeros chilenos que pasaron por Lima, hace algún tiempo, entre ellos Joaquín Edwards y Schneider Labbé, anotaron la inquietud sospechosa del ambiente peruano. No todo era oro en la brillante exterioridad del gobierno de Leguía. Faltaba allí la austeridad, la sobriedad. Parece ser que el punto débil de las democracias americanas es el olvido de la virtud de la sobriedad. La economía política se vuelve una ciencia difícil cuando los pueblos olvidan su origen. Les acontece lo que a los individuos de oscura extracción que de la noche a la mañana se ven dueños de una cuantiosa fortuna. Enloquecen y lo echan todo por la ventana. Parece que Leguía se dió cuenta o despertó de su pesadilla de millones sọ́lo en el camarote custodiado del "Grau», a varias millas de la costa y sin puntos de contacto con la realidad que lo había visto impasible derrochar los fondos del Estado.

El proceso del drama peruano, cuya culminación acabamos de ver, es un proceso de formación intelectual. No esbocemos la sonrisa del desdén ante la insinuación siquiera de un término tan desprestigiado 
en América. Pero la realidad actual del Perú, la forma misma de su violencia revolucionaria, no son más que los ecos con que responden a Mariátegui y sus colaboradores las palabras metálicas y estridentes de Sánchez Cerro. En el fondo, este militar sigue la trayectoria de la flecha del austero pensador peruano. Claro está que no en la esencia, puesto que Mariátegui era un heredero de Marx, pero sí en la intención depuradora. Nadie como Mariátegui removió en el Perú la ciénaga de la realidad social, la miseria del indio explotado, la descomposición política, la indiferencia del nuevo rico ostentoso que surgía en Lima, amparado por el gobierno de Leguía. Mariátegui estaba tumbado en su sillón de inválido, impotente en su debilidad física. Pero iqué noble y qué austero en su pobreza! Aquel hombre pequeño y magro de carnes era un cerebro poderoso que vigilaba la tierra de sus mayores, la tierra tradicional que debe defenderse y engrandecerse. $Y$ así, mientras Leguía tiraba por la ventana los fondos públicos que recogían sus colaboradores, Mariátegui hacía en su modesto escritorio de pensador, en lucha con la pobreza, el proceso implacable de la política peruana. Desde las columnas de Amauta difundía su pensamiento tutelar, a través de Lima y de las ciudades, a lo largo de la sierra y de los campos. Al modo de una llama nerviosa de fuego, la palabra de Mariátegui iluminaba la tiniebla que ocultaba el drama de la realidad.

Porque en verdad, en la situación económica del Perú, no había equivalencia alguna entre la riqueza aparente y el empleo que de ella se hacía. Leguía estaba bien en el palacio de los Virreyes, pero la realidad desharrapada rondaba y silbaba en torno al desequilibrio de la política económica. Lima absorbía la vitalidad peruana. Había heredado la tradición áurea del virreinato. Era la apariencia ostentosa y rica que cubre la pústula y como estaba mal gober- 
nada, era incapaz de someterse a la escueta verdad de las cifras. Modernizaba, ciertamente, sus rincones; abría anchas avenidas asfaltadas, elevaba hacia el cielo calcinado la flecha de sus palacios suntuosos, entre los que sobresalía el del Arzobispado, pero en las provincias el modernizamiento era nulo. Llenaba sus calles de lujosos automóviles-el año 1929, según la estadística que confrontamos, entraron en Lima 8,000 - , permitía oficialmente el juego, y los hombres asiáticos abrían en todas partes fumaderos de opio y casas de juego; los funcionarios y amigos de Leguía percibían gruesas coimas por estas concesiones y lentamente se formaba una espesa capa de prostitución. La mujer, sin recursos para llevar una vida ostentosa, como exigía el tren desorbitado de gastos del gobierno, debía salir a la calle a remediar su miseria. Mientras las cifras de la estadística anotaban gruesas cantidades florecientes, la pobreza doméstica empujaba a las jóvenes hacia el vicio. En cambio, la realidad del obrero, substituído por elementos asiáticos en las obras de construcción, y las concesiones cada vez más ingentes a los capitalistas extranjeros, labraban, poco a poco, el desconcierto y la ruina.

En la política peruana no había ningún sentido de la responsabilidad y de la sobriedad. Leguía tenía su corte de adoradores que lo incensaba y que le impedía oír el rumor que surgía de las provincias y de los subterráneos de Lima. Gobernaba en realidad, para unos pocos, a los que hacía sentir todo el peso de sus leyes arbitrarias. Véase, por ejemplo, cómo Sánchez Cerro, con una trágica ironía, lo ha hecho custodiar por los mismos a quienes él había mantenido encarcelados durante años. Sistemáticamente se abominó en el Perú de la palabra "política». Fué proscrita de todas las asociaciones, de todas las formas de la vida real. El escritor mismo dedicó su actividad a cantar o describir una exterioridad que no le permitió nunca 
ahondar en la médula vital. Era retórico que deleitaba a las damas. Por eso Leguía pudo gobernar sobre una superficie en la que no aparecían conciencias. Cuando aparece Mariátegui, con él hace irrupción el sentido político más austero. No sólo en el pensamiento peruano promueve un cambio radical, sino que la realidad social se siente galvanizada por la palabra del joven pensador. No es la política electoral que prolonga el cacicazgo o la que procedía por prebendas y premiaba los servicios y las genuflexiones con puestos y viajes, como hizo Leguía, sino esa ciencia inflexible que está sostenida por una gran idea moral, que es superior a las alternativas de una realidad circunstancial, que toma la realidad misma de que está amasada la sociedad, para enderezarla por un camino de justicia y de honradez.

La intelectualidad peruana le debe mucho. Desde luego, el haber podido descubrir los problemas sociales y políticos de su tierra, que son comunes a todos los ciudadanos, pero que necesitan guías a fin de poder moverse a través de los obstáculos que le opone una estructura política vieja y carcomida. El Perú le debe su renovación. Le debe quizá esta sacudida que ha trastornado la vida política criolla, dejando al descubierto las culpabilidades y los errores de los antiguos gobernantes peruanos, y aun cuando no es justamente la forma de conmoción social que soñaba Mariátegui, es por lo menos una etapa depuradora en la evolución del Perú, en el que Mariátegui continúa viviendo en espíritu y presidiendo todas las formas del pensamiento noble y enaltecedor. 